Final article:

Vallaster, C. and Lindgreen, A. (2011), "Corporate brand strategy formation: brand actors and the situational context for a business-to-business brand", Industrial Marketing Management, Vol. 40, No. 7, pp. 1133-1143. (ISSN 0019-8501)

For full article, please contact LindgreenA@cardiff.ac.uk

\title{
Corporate Brand Strategy Formation: Brand Actors and the Situational Context for a
}

\section{Business-to-Business Brand}

\author{
Christine Vallaster, University of Liechtenstein ${ }^{1}$
}

Adam Lindgreen, Cardiff Business School \& IESEG School of Management ${ }^{2.3}$

\footnotetext{
${ }^{1}$ Dr. habil. Christine Vallaster, Institute of Entrepreneurship, University of Liechtenstein, Fürst Franz-Josef Straße, 9490 Vaduz, Liechtenstein. E-mail: christine.vallaster@uni.li.

${ }^{2}$ Professor Adam Lindgreen, Cardiff Business School, University of Cardiff, Aberconway Building, Colum Drive, Cardiff CF10 3EU, U.K. E-mail: LindgreenA@cardiff.ac.uk.

${ }^{3}$ Both authors contributed equally. They thank two anonymous reviewers and the guest editors for their comments and suggestions throughout the review process.
} 


\title{
Corporate Brand Strategy Formation: Brand Actors and the Situational Context for a Business-to-Business Brand
}

\begin{abstract}
Prior literature on corporate branding in the business-to-business (B2B) context fails to provide insight into the dynamics of corporate brand strategy formation, despite the critical need for industrial organizations to move beyond a traditional understanding of brands. This article examines the corporate brand strategy formation of a European-based industrial organization by drawing on strategy-as-practice research and thereby identifying the brand actors who participate in corporate brand strategy formation, the construction of manifestations that subject the brand values to experience, and the situational context-all within a single, ongoing, recursive interaction process.
\end{abstract}

Keywords: business-to-business brands, corporate brand strategy formation, corporate brand strategy manifestations, brand values, brand actors, situational context, social interactions. 


\section{Introduction}

Corporate branding's relevance in the business-to-business (B2B) context is increasing as industrial marketers focus on building their brand(s) at the corporate level (Beverland, Napoli, \& Lindgreen, 2007; Glynn, 2010; Kuhn, Alpert, \& Pope, 2008; Low \& Blois, 2002). Successful branding at this level requires corporate brand values to become the organization's "central organising thought" (Macrae, 1999: 8) and a filter that guides employee behavior (Keller, 2003). Existing research notes the resultant need to communicate not only a product's price and functional features (Bendixen, Bukasa, \& Abratt, 2004; Mitchell, King, \& Reast, 2001) but also its salient intangible associations, such as expertise and trustworthiness (Beverland \& Lindgreen, 2002; Glynn, 2010; Mudambi, 2002; Persson, 2010; Webster \& Keller, 2004). Such communication should originate with employees and spread through relevant customer touch points (Mudambi, 2002; Persson, 2010; Webster \& Keller, 2004); to ensure such paths, corporate brand values ${ }^{4}$ must adopt generalized meanings within the organization.

The strong corporate brand that can result from this process has significant benefits in various contexts, including mergers and acquisitions (Lambkin \& Muzellec, 2010) and manufacturer-reseller relationships (Glynn, 2010). Yet the dynamics of the branding processes remain unclear. First, to our knowledge, no existing research examines the brand actors involved, that is, the people who participate in branding (Mühlbacher \& Hemetsberger, 2008). Although leaders have been identified clearly as critical drivers (Vallaster \& de Chernatony, 2006; Lindgreen, Maon, Xu, \& Wilcock, 2011), the role of other actors, both internally and externally, has not been addressed. Second, the impact of each actor's social interactions in branding has not been considered. For instance, only little research has addressed the mechanisms through which such interactions take place, for example meetings

\footnotetext{
${ }^{4}$ We use the terms "brand value" and "value" interchangeably. We similarly use "brand actor" and "actor" interchangeably.
} 
as a way to develop branding strategies (de Chernatony, Drury, \& Segal-Horn, 2006). Third, research examining brand-supportive behavior shows that personal interest influences actors' choices of brand practices (Burmann \& Zeplin, 2005; Thomson, de Chernatony, Arganbright, $\&$ Khan, 1999), but the question of how situational (i.e., individual, organizational, or marketrelated) contexts influence brand strategy formation remains unanswered. For instance, individual-related context such as motivation ("what's in for me?") greatly determines the degree to which an employee is likely to engage in brand strategy formation. With regard to organizational-related context, different divisions or sub-units of an organization may follow different goals, which in turn may determine the priority with which an overall brand strategy is followed. Finally, market-related context refers to the way that satisfying customer (or other stakeholder) needs, or competitive moves, may influence brand strategy formation.

In particular, there is "little research ... on key strategic and tactical issues in relation to building, managing, and refreshing business brands" (Lindgreen, Beverland, \& Farrelly, 2010: 1223-24). Efforts increasingly focus on the brand itself and related economical aspects; however, if researchers are to help practitioners formulate more effective brand strategies, we first need a deeper understanding of what practitioners actually do.

Therefore, we draw on the ideas promoted in strategy-as-practice research (Chia, 2003; Hendry, 2000; Jarzabkowski, 2005; Jarzabkowski, Balogun, \& Seidl, 2007; Johnson, Langley, Melin, \& Whittington, 2007; Whittington, 2003) to illuminate branding processes by distinguishing among the practice lens (brand strategy as situationally and socially accomplished), brand practices (actual activities by the organization), and brand practitioners (skilled actors involved in brand strategy making) (Balogun \& Johnson, 2004; Maitlis, 2005; Maitlis \& Lawrence, 2007; Rouleau, 2005; Whittington, 2006). For the purpose of this study, we define brand strategy formation as a process and consider both simultaneous and 
reciprocal attempts to influence corporate brand understandings and generate shared brand meanings.

To contribute to literature on how $\mathrm{B} 2 \mathrm{~B}$ brand actors participate in the interactive space of brand strategy formation, we highlight situational elements and address two key research questions. First, what role do company internal and external brand actors play when participating in brand strategy formation? Second, how does the situational context drive brand strategy formation and thus help establish a strong corporate B2B brand?

We structure the remainder of this article as follows: First, we review challenges in brand strategy formation in a B2B context and thereby describe brand strategy formation by (1) defining corporate brand and brand values, (2) identifying brand actors and their social interactive mechanisms, (3) outlining brand strategy formation practices, and (4) analyzing the influence of the situational context on brand strategy formation. Second, we detail the qualitative case study we employ in this article. Third, we present and discuss our research findings. Fourth and finally, we identify the study's theoretical and managerial contributions, as well as some limitations and avenues for further research.

\section{Literature review}

Corporate brand strategy formation is a complex process. For B2B organizations to coordinate the various activities of their organizational brand actors and influence social interactions between the organization and its stakeholders, they need an in-depth understanding of the dynamics that shape their brand strategy formation (Lindgreen, Beverland, \& Farrelly, 2010).

\subsection{Corporate brands and brand values}

Corporate branding applies a single brand across the entire organization; the corporate culture becomes the very foundation of the corporate brand (Hatch \& Schultz 2001, 2003). To define fundamentally what an organization is, the corporate culture must encompass corporate values 
(Balmer \& Wilson, 1998; Van de Veen, 2008). Such values are necessary to an organization, but a corporate brand also is contingent on the promise made to external stakeholders (Balmer \& Grey, 2003). In this sense, a corporate brand involves values that distinguish it from competitors, assuming those values are congruent with the corporate culture. For example, the Liechtenstein-based power tool company Hilti promises it will "Outperform. Outlast," and its corporate cultural values mirror this concept (e.g., to act with integrity, demonstrate courage to go beyond its habits, outperform through teamwork, commit to personal and organizational growth). To develop a consistent brand image, Hilti must make all these 'brand values' explicit to its stakeholders, who then ascribe meaning to the organization-ideally, congruent with the corporate culture - as a result of their brand experiences (Hatch \& Schultz, 2001, 2003; Schultz, Hatch, Larsen, \& Van Riel, 2002).

\subsection{Brand actors and the social interactive mechanism of brand strategy formation}

Brand management literature often focuses on the contributions of the CEO or top management team in influencing what the branding strategy means, how it is enacted, and how its associated processes might be managed (Aaker \& Joachimsthaler, 2000; Davis \& Dunn, 2002; Vallaster \& de Chernatony, 2006). However, leaders are not the only actors who give sense to employees (Mintzberg \& Raisinghani, 1976; Mintzberg \& Waters, 1985). For example, industrial marketers need a "bottom up and top down approach to brand building" (Webster \& Keller, 2004: 398) and actively engage employees in the brand building process. Thus middle managers - who mediate between the organization's internal and external environments - strongly influence brand-related processes (Floyd \& Wooldridge, 1997; Schilit, 1987; Wooldridge \& Floyd, 1990). Adopting a sense-giving and sense-making perspective for the analysis of brand strategy formation results in seeing such processes as an interactive process (Laroche, 1995) that consists of conversational and interaction practices such as workshops, events, or away-days (Balogun \& Johnson, 2005). These practices feature 
participants from inside and outside an organization who show varying degrees of intention, interest, and intensity (Jarzabkowski, 2004; Johnson, Melin, \& Whittington, 2003).

Most current literature cites three main brand actors: managers who drive the branding strategy (Keller, 2003); consumers who use, alter, or reject brand meanings (Kates, 2004); and stakeholders, such as employees, suppliers, shareholders, various regulators, and local communities, that create and develop brand meaning (e.g., Hatch \& Shultz, 2003). Little branding research, especially in a B2B context, explores and describes their interactions. For example, are corporate brands predominantly constructed internally, externally, or in cooperation (Roper \& Davies, 2007)? Recent research in the Trappist beer industry suggests that "brand meaning is not the sole province of marketers but also draws on the institutional environment surrounding the brand" (Lindgreen \& Beverland, 2009: 81). The development of each Trappist brand thus results from complex interplays among brand managers (i.e., individual or organizational), the institutional (i.e., market) environment, business buyers (i.e., individual or organizational), and consumers (i.e., individual).

To the best of our knowledge, no research defines clearly how various actors—such as employees from different organizational divisions, external partners, and customers - who are embedded in branding strategy formation actually come to agree on its manifestation (Mühlbacher \& Hemetsberger, 2008). By brand manifestation we mean tangible and intangible objectifications of the meaning of a brand. For instance, the Hilti brand is manifested in various way (i.e., through its products, staff behaviour, and communication). Hence, brand manifestations allow employees and other stakeholder groups to experience the meaning of a brand (Mühlbacher \& Hemetsberger, 2008). Examining the issue of brand manifestation agreement represents a response to calls for a deeper understanding of brand development and maintenance (Lindgreen \& Beverland, 2009).

\subsection{Situational context of brand strategy formation: individual context and beyond}


If employees know the brand values and consider them relevant, they may start to identify with the brand and behave accordingly (Burmann \& Zeplin, 2005). Contemporary strategy research thus proposes conceptualizing strategically relevant (branding) cognitions as schemata (Rouleau, 2005) or "accounts" (Maitlis, 2005) that construct a stepwise view of ongoing strategy formation. Thus brand strategy formation occurs in the movement from one schema to the next. At any point in time, individual schemata "constitute a mix between old schemata that have not been challenged, schemata in the process of transition, and schemata that have already been changed" (Balogun \& Johnson, 2005: 1588). This conceptualization cannot explain though how context-dependent (situational) individual brand constructions exist in conflict with socially accepted (situation-independent) brand constructions (cf. Garud \& Rappa, 1994). For example, employees might agree with and be highly committed to strategic branding projects overall, but they probably have differing opinions when it comes to the changes required for their own business units. Even if people hold different viewpoints, they can collaborate effectively during strategy making (Eden \& Ackermann, 1998; Mezias, Grinyer, \& Guth, 2001; Van der Heijden \& Eden, 1998); they also demonstrate idiosyncratic beliefs when they consider intentional non-adherence (Thomas, Clark, \& Gioia, 1993; Thomas, Shankster, \& Mathieu, 1994). Intentional actions appear in traditional research into observable strategy formation processes, though Mintzberg (1995) also highlights unintentional facets of strategy making, in which the brand strategy emerges over time as intentions collide with and accommodate the changing reality.

Thus to advance knowledge about brand strategy formation, we need a better understanding of social interactions across interested individuals, groups, and organizations, both internal and external to the focal firm. We also pick up the perspective that brand strategy formation may happen in two ways, that is in intentional and unintentional ways. 


\section{Methodology}

\subsection{Case study and case company}

We adopt a case study method (Yin, 2003), which focuses on understanding dynamics in specific settings (Eisenhardt, 1989; Woodside, 2010). To define the unit of analysis, we apply Yin's (2003) criteria: (1) It must relate clearly to the main research question; (2) it should represent an extreme case; and (3) it is possible to delineate the unit of analysis clearly. The European company HighRingTech, ${ }^{5}$ an internationally oriented, family-owned organization, meets all these criteria. This firm, about 150 years old, sells a broad range of industrial products such as vibration control components, nonwovens, and household cleaning products. Figure 1 illustrates the organizational structure of the business segment that we analyzed, namely, business area A, which comprises three business groups: Vibration Control Europe, Vibration Control America, and Vibratech Europe. In total, the unit employed approximately 20,000 employees at the time of our investigation.

\section{\{Insert Figure 1 around here $\}$}

Since the mid-1990s, HighRingTech has officially cited five brand values and guiding principles for daily behavior: innovation, leadership, people, responsibility, and long-term orientation. In early 2002, it added one more brand value: value for customer. The company believed that being passionately committed to anticipating, understanding, and meeting customers' needs and expectations empowers their customers to be successful. Their global presence is believed to provide the company with a competitive advantage.

Yet HighRingTech began as a technologically oriented culture, which meant it had significant work to do to ensure a positive customer experience. In particular, according to its chair,

\footnotetext{
${ }^{5}$ For confidentiality, we use this pseudonym instead of the company's actual name.
} 
Due to our historic roots we had - and partly still have - a fiddling culture: a great majority of our staff has a technically-oriented background; we were always highly innovative and put about $6 \%$ into our research and development program. However, it could happen that we developed products that customers did not accept. It was, therefore, not surprising that we were not perceived as an innovative company as we lost touch with reality.

HighRingTech's major weakness was that it ignored customers' needs and failed to listen to what customers told them. The director of sales reported some common business practices:

When we visited our customers and we had an hour to present our products, we took information material for two hours with us. We actually tended to plaster our customers with information and we did not ask them for their opinion. We simply did not care.

A customer satisfaction analysis, conducted between 1995 and 2001, always provided the same results: The Vibration Control segment was losing its dominant position. In response, HighRingTech introduced its "Ultimate Customer Orientation" (UCO) initiative in early 2002, designed to be an ongoing effort that would use customer satisfaction reviews as measures of improvement.

\subsection{Research methods}

To gain a description of the UCO initiative, the first author conducted interviews with 20 employees, focusing particularly on marketing managers and members of the brand team responsible for global brand management, as well as the employees of external partners (e.g., consulting agency, suppliers, market research company). The selection of interviewees reflected their involvement in the UCO program, such that we pursued a good balance between active ${ }^{6}$ and passive ${ }^{7}$ participants, as we detail in Table 1.

\{Insert Table 1 around here\}

Each interview lasted an average of two hours. The first author also visited each case site and gathered additional information from conversations, observations, and other in situ techniques. Prior to each interview, publicly available secondary data and promotional

\footnotetext{
${ }^{6}$ Active participants include people who were involved in planning the UCO program.

${ }^{7}$ Passive participants include people who were mainly 'executors' of the UCO program, giving feedback as regards to progress and success of the program.
} 
information provided by the company and external agencies were reviewed to gain greater familiarity with the case.

The interview questions focused on gathering a descriptive history of the motivation to focus on the customer, associated pressures, major objections, relationships with other brand values, support (or lack thereof) for brand strategy implementation, and levels of success, as well as the determinants of this performance. The interviews started with broad, "grand tour" questions that enabled the informants to present the material in their own terms. These questions appeared interspersed with specific prompts designed to induce greater insights into specific lines of inquiry, such as details about particular programs. Although a short, standardized guide was used for each interview, our data gathering also reflected emerging topics that appeared in any interviews. We detail the interview guidelines in Table 2.

\{Insert Table 2 around here $\}$

After the interviews, we analyzed any further information provided by the informants or other sources. By drawing on secondary data and multiple interviews with different company stakeholder groups, including customers and external agencies, we develop rich insights and support the transferability of our findings to other contexts (Eisenhardt, 1991).

\subsection{Data analysis}

We first analyzed the case to gain a richer understanding of the brand strategy formation that HighRingTech undertook. We aimed to identify brand actors participating throughout the process, formal and informal processes of social interaction, branding practices, and situational contexts. Simultaneously, we elaborated on theoretical categories using open, axial, and selective coding (Strauss \& Corbin, 1998). For the open coding process, we read and examined discrete parts of the interview transcripts to identify similarities and differences. Each author performed this analysis independently and classified each interview section according to an initial coding scheme that comprised social interactions applied, 
branding practices taken, and brand actors. The authors then met to discuss and reach agreement on any portions of the analysis subject to disagreement.

With axial coding, we reassembled the data into categories and subcategories to reveal the role of the situational context on the brand strategy formation process. For example, due to their unique and often particular characteristics, different people within the company tended to focus on specific issues that they believed were the most appropriate and relevant. Their beliefs about what constitutes a branded organization depended on their perspective. Yet people's expectations are not only inconsistent (Dawson, 2003) but also inexorably evolve over time (Jawahar \& McLaughlin, 2001), so brand strategy formation requires constant reassessments and dialogue between the organization and its brand actors. Our first brand strategy formation code therefore consists of various internal (e.g., CEO, communication, production, marketing) and external (e.g., customers, consultancy agency) brand actors.

Finally, to gain a holistic, contextualized comprehension of how the company approaches its aim of becoming more customer oriented, we tacked back and forth between prior literature and our data to develop several theoretical categories (Spiggle, 1994). For example, our analysis revealed that different stakeholders play different roles in brand strategy formation. To understand these shifts, we consulted extant literature.

Throughout the study, we also adopted several methods to ensure quality. Consistent with recommendations from interpretive researchers (Lincoln \& Guba, 1985), grounded theorists (Strauss \& Corbin, 1998), and previous case-based research (Beverland \& Lindgreen, 2010), we applied credibility, transferability, dependability, confirmability, integrity, fit, understanding, generality, and control criteria. In particular, we conducted multiple interviews, established our own independent interpretations of the findings, and allowed respondents to provide feedback on our initial findings. All interviews were conducted by the first author, and additional colleagues performed the independent coding of the transcripts, 
which reduced the potential for bias (Lincoln \& Guba, 1985; Strauss \& Corbin, 1998), as we detail in Table 3.

\{Insert Table 3 around here $\}$

\section{Research findings}

In structuring this section, we first describe the starting point for brand strategy formation, then identify the brand actors and the social interactions that characterized the brand strategy formation. We also describe brand strategy formation practices. We conclude by describing the influence of situational contexts on brand strategy formation.

\subsection{Starting point and employee reactions}

In September 2001, the management team of HighRingTech awaited, with increasing tension, the results of a customer satisfaction survey. An external market research agency, responsible for conducting customer research on a regular two-year basis, presented the results: For the third consecutive time, the organization's performance had fallen in comparison with that of its competitors. The audience reaction was mixed, ranging from true consternation to frustrated utterances of "Yeah, right, no wonder if the wrong people are being asked," "the results are not worth the paper it is written on," and "I can't see these results mirroring my area's performance." Many of the employees were simply shocked when confronted with the negative assessments customers offered of their experiences, but the chair of the board made one point very clear:

We have to move! These results are disastrous. We are being rated worse almost on all items if compared to our competitors. We can no longer afford to lose any more market share. And I am sick of talking against the wall: Despite communicating the results of the survey from the last two years on a very regular basis and many meetings with the responsible people, nothing happened. It seems that the impact was zero. If we want to succeed in the future, we need to go through a major branding program.

Soon after the release of these disastrous results, HighRingTech decided to roll out a program called "Customer Orientation First" (UCO). The organization introduced three corporate-wide initiatives, each of which we discuss in subsequent sections: 
- Internal actions, for example official documentation, UCO logo and principles, communication, and awards (see section 4.2.2).

- External actions to intensify customer relationships, including reworking logistics, complaint, and innovation-led processes, for example translation of customer requirements into processes and activities, development of collaborative interdepartmental relationships, and documenting customer-specific roadmaps (see section 4.3).

- Training under the heading "value selling," for example change agents and brand champions (see section 4.2.1)

These activities aimed to anchor the meaning of UCO (i.e., anticipate, understand, and meet customers' needs and expectations) in HighRingTech's organizational culture and thus to facilitate changes to the rather technologically oriented mindset of employees, moving them toward a more customer-oriented corporate brand. At the outset, HighRingTech management set a target score of 8.0 for overall customer satisfaction (on a 10-point scale), to be achieved by all business groups by 2003. Their average satisfaction score in 2001 was 7.2 , so this target was considered ambitious.

\subsection{Brand actors and social interactions}

\subsubsection{Brand leadership practices at all levels}

The official support provided by top management at the start of the UCO initiative seemed to be a crucial success factor that signaled the importance of delivering more value to the customer. However, accepting the role of change agent was tough, as the chair reported:

You need to be the first to change, you need to be very clear of the goal and what your next steps are, you need to take tough questions, you need to be tough yourself but listen to your employees' problems at the same time, you need to be visible for your own people and at the customers' site, and you need to be patient as changes are longdistance races.

Brand strategy formation was unlikely to succeed as a one-person show; the demand for strong leadership thus required effort at all levels of the organization (Ind, 2007; LePla \& 
Parker, 1999). To address this issue, the company extended its top and middle management and added new members without nostalgia for the former strategy. To help transfer UCO principles throughout the organizational hierarchy, about 20 managers from all levels (Figure 2) were tagged to act as champions, because their experiences and personalities would enable them to promote an agreed value system based on a commitment to increase customer satisfaction, collaboration, professional development, and mentoring, as well as performance in accordance with the organization's standards and culture.

\{Insert Figure 2 around here

In a first step, these brand champions received introductions to the UCO philosophy. Their task was to develop ideas for training that would be needed to disseminate the strategic brand goal of selling customer solution packages rather than individual products. In two workshops, mediated by external consultants, HighRingTech gathered these ideas and decided how to launch "Value-selling training." The primary message was in accordance with the brand value, "customer orientation first," and it emphasized that the higher selling price for the solution package ultimately would mean lower costs for customers. Salespeople, technical engineers, marketers, leaders, and middle and senior managers (including the chair) learned how to translate the immediate benefits that a product delivered into dollars-and-cents financial impacts for customer, then reveal how higher priced but differentiated products would cost less than those offered by competitors. Another part of the agenda was ensuring accurate training and preparation for customer visits and interviews, including ways to listen to customers and ask the right questions.

More than 100 employees underwent the initial training session organized by the external consultants and received certificates that qualified them to conduct similar training sessions. Ultimately more than 500 training sessions, with roughly 8,000 employees, took place; the educational materials also were translated into 35 languages. 


\subsubsection{Communication practices revisited: communicating importance of brand strategy}

formation

To make the customer more visible - not only in in-house media but in offices and at the production site-HighRingTech needed to revise its regular communication practices. This shift required the strong involvement of the human resources and communications department (Aurand, Gorchels, \& Bishop, 2005). The chair summarized the challenges:

You need to touch base with thousands of people, telling them why it is important to change. People have to understand the essentials of UCO and that we will be more successful by doing that.

This challenge particularly emerged with regard to communicating the importance and meaning of the brand strategy formation to different people with different mindsets (Aaker \& Joachimsthaler, 2000; de Chernatony, 2010, Salzer-Mörling \& Strannegard, 2004). The director of sales, who headed the largest business group in the segment, noted:

It is important to know with whom you are talking to. We needed to target employees working at the production lines, with controllers, with sales people, etc. They all hear and understand something different when talking about UCO; the degree to which they attached importance to that process differed and so was their willingness to participate and drive brand strategy formation.

To minimize potential conflict, the primary decisions focused on whether the internal communication campaign would be developed centrally or for different business areas; if it were developed centrally, the top management team would need to acknowledge each decentralized organizational structure and grant the various business areas significant entrepreneurial responsibility. If employees would not join the communication program, the entire success of the UCO effort would be at risk. The person responsible for internal communication thus reflected:

After a few discussions, it was decided that the main goals and topics of the UCO communication campaign were to be developed with the help of external agencies based on our detailed briefing. Our consultants, our Chair, and myself had the final say, but the various business areas had quite a lot of freedom in implementing the communication strategy. Also, they could count on the help of our PR department that supported the roll-out of the communication campaign by providing communication material such as posters or flyers. 
In addition, several practices were identified as central to the success of the internal communication program. First, to clarify the purpose of UCO, the company developed an official document that listed its main topics and translated it into the seven languages used throughout the organization. An external agency also produced the UCO logo. The cooperation between this agency and HighRingTech was a dialog-based, give-and-take relationship, a consensus opinion among all those involved:

To make sure they developed a sign that characterizes the UCO efforts, we intensively exchanged our ideas, which of course led to some re-definition of some planned UCO steps and practices, but in its essence the strategic aim remained the same.

The use of a single logo and official document helped employees acknowledge and recognize the goals of UCO, as well as internalize its principles and become more customer oriented.

Second, to facilitate communication with and among employees about UCO success steps and practices, HighRingTech used both face-to-face and virtual communications. Advanced data networks linked the internal teams and enhanced the exchange of UCO knowledge. To encourage employees to adopt practices that were particularly successful in one area and apply them in their own business fields, the company broadcast over its intranet the "best practices" achieved by different departments, with the motto "Steal Shamelessly." For every story posted, the posting department received a green point, assigned by an external consultancy company. The first department with five green points earned special credit and recognition. As the logistics manager recalled,

At first, this initiative did not seem to be very fruitful. Months passed and nothing happened. Actually, rumors had it that this was an artificially created competition amongst departments, facilitated by an external agency - as if we had nothing better to do. Then it was our department that posted our first story ... and a few months later, we posted our second story. We received two green points and everybody could see this. Suddenly something strange happened - within two weeks, six other departments launched their successful stories and practices and many more followed; a real hype was initiated.

This communication practice seemed to intensify lateral connections and competition across functions, because the information was accessible to everyone. 
Third, success stories, including UCO awards on the sales and business group levels, aimed to imprint UCO in people's memories. To induce employees to talk or write about UCO, the company printed and distributed success stories in its in-house newspaper, (available in seven languages), which also underwent a complete style and content revision. Previously, the focus of the newspaper had been on top management and their actions; in the revision, their contributions shrank to just the editorial feature, and employees and customers received the bulk of the attention. This content often highlighted how staff members could produce a more customer-oriented company, featured customer success stories, or depicted customer logos.

Fourth, cards printed with the UCO principles were distributed to all employees, and installed screens and posters at production sites depicted customer-oriented information, such as complaints or thank-you letters. The creativity displayed in facilitating social interactions knew no bounds; for example, one initiative organized quizzes that tested players' product knowledge. Participants who answered questions about the firm's products and their locations in the customer's car product correctly could receive that car for a weekend. Smiling face images identified strong performance and positive news; newly developed boards showed the customer for which the products were being produced. Whereas previously production lines took names such as VK 1, 2, or 3, they now received new names that indicated the key accounts, such as BMW production, Ford production, and so on.

\subsection{Brand strategy formation practices: translating customer requirements into changed processes and operational activities}

In focusing on how to facilitate internal communication practices within the company, as well as how different organizational cultures might be integrated to enhance learning, HighRingTech launched a program called CIP ("Continuous Improvement Processes"). The idea was to translate customer requirements into changed processes and operational activities 
quickly and effectively, modeled after Japanese "kaizen" projects that pursue steady change for the better. In the CIP program, teams from different departments and functions would work together for a few days to formulate specific solutions to a very specific problem. This approach reflects the recommendations of Homburg, Workman, and Jensen (2000), who suggest using groups of customers and their requirements as the primary basis for an organizational structure.

In addition, so-called "common issue teams" were tasked with identifying internal problems related to concerns that appeared in the customer satisfaction analysis, such as delivery performance, quality defects, or innovation lead times. These teams then worked to improve the underlying processes by intensifying and improving relationships with logistics, suppliers, and further back in the value chain. The key account manager of one of the biggest raw material suppliers to HighRingTech recalled:

In the initial stages, we-dealing with HighRingTech and knowing their technologically-oriented culture-were really skeptical when we learned about their efforts in focusing more on their customer needs. First, what is it that we have to do with their customers - but then we started to understand that they were really getting into it and that we also profit from their better customer-oriented performance. So it was really a learning process for both of us.

Another effect was the development of strong collaborative interdepartmental relationships, which enhanced searches for customer solutions and the coordination of pertinent information (Workman, Homburg, \& Jensen, 2003). The results of this teamwork were implemented directly, with their outcomes closely monitored. The teams had wideranging autonomy and decision-making prerogatives, which reflected and underlined the company's basic goal to transfer more responsibility to associates and encourage them to make continuous improvements a permanent part of their daily work life.

Overall, these brand strategy formation practices, designed to intensify customer relationships through regular, timely, relevant communications of customer needs and related strategies, appeared to have a positive impact on customer value creation. A nearly intimate 
relationship with customers developed, for which regular customer visits by HighRingTech employees from all business areas were considered crucial. Not just sales but also employees from product development, quality, and logistics visited customers. To intensify customer contacts on all levels and functions, each area developed customer-specific roadmaps. A particularly viable connection with customers emerged from efforts to address issues such as particular weaknesses and problems mentioned in the customer satisfaction survey, as well as discussions of ways to improve the relationship. According to the sales director, such efforts were "perceived as something exceptional, as the feedback made our customers feel valued and heard."

\subsection{Understanding the influence of the situational context}

Our analysis revealed that individual, business group-specific/organizational, and marketrelated contexts all influenced the brand strategy formation by facilitating or hindering the process.

\subsubsection{Individual context: Developing a sense of customer orientation among employees}

Lack of language skills: The first difficulty in expressing the need to develop a more customer-oriented culture was that many of the actors simply did not understand the English phrase "customer orientation first." The sales manager (VK 1) reported, "Most of the people at the production line don't speak English. Hence, the phrase 'Customer Orientation First' was not understood by most of the people - and therefore widely ignored at first." As a response, management renamed the entire initiative using local languages (German, Dutch).

Lack of motivation: The newly applied internal communication practices were not enough to induce sensitivity in employees' attitudes toward customers though (not to mention their behaviors). Much of the information was never read; if read, it was often considered incredible or overly hyped by management (Larkin \& Larkin, 1996; Lencioni, 2002). To try to address this issue, the company invited customers to visit production sites on a more regular 
basis and illustrate the end product for which the HighRingTech products were used. The sales manager (VK 2) remembered his experience: "One of our customers aptly described what happened if our product was not manufactured properly - the bus would drive against the wall." These presentations about the importance of delivering high-quality products helped enhance the credibility of UCO among workers at the production site.

Resistance to change: Fatigue in response to "yet another campaign" created another issue. The head of the internal communications department explained:

Being confronted with a new program, many employees think that what they have been doing so far was bad. We put a strong focus in emphasizing good examples that were already existed ... and as time passed and also customers came up with rewarding words and statements, we felt that our employees lost their cynicism to a great extent. In fact, today employees call the editors and tell them about particular customer-oriented solutions.

\subsubsection{Business group-specific/organizational context: Addressing employee resistance to}

\section{customer orientation}

Information flow: Management was aware that the UCO brand strategy formation process would be long-term and ongoing, yet it still underestimated the difficulty of communicating the guiding principles to some 20,000 employees. Although UCO and its related programs overall were considered a success, the degree to which the initiatives were accepted depended a lot on the flow of information, enabling the implementation of UCO. According to one manager, "the implementation in our business group was too slow - I know from other groups that were much quicker, therefore experienced many more quick-wins and therefore had much more energy to work on certain issues." Also, the overuse of virtual media such as the intranet led many employees to ignore UCO-related messages.

Incentive system: Attempts to motivate resistant employees were particularly challenging and varied across business groups. The workers' committee limited any termination of such workers, though some business groups attempted to exert pressure through performance measures. Yet consequences such as revised reward systems remained an individual issue, 
and setting goals related to UCO required a personal commitment. The sales director explained that "linking customer-oriented behavior to an individual performance system would require an additional shift in our corporate culture; we are not there yet although, in my opinion, this would be the viable way to go. At the moment, we are setting individual goals and exert more informal pressure if you wish to say so; however, this practice varies considerably between our business groups."

Training offers: Although the training offered was widely considered a good tool for enhancing understanding of the UCO content and facilitating employee identification, employees hired after 2004 reported that they received no training at all. Asked whether this was a specific business group practice, one customer complaint manager noted, "When I had my first day in this business group, I was told that I should develop some customer plansand that was it. No explanation, no nothing. I know that this introduction varied considerably." Reasons mentioned included possible budget restrictions for training sessions, as well as brand champions who often became fatigued, which hindered their advice to colleagues.

\subsubsection{Market context: addressing customer orientation through feedback and satisfaction}

Already at the earliest stages, critical statements appeared regarding the items used to measure customer satisfaction. For example, in 2002, the director of sales remarked:

During the past years we have not done anything else than implementing new UCO initiatives. And in sum it seems to work - the customers are coming back to us.... And yet our company was rated lower on the item Price/Performance ratio if compared to main competitors (director of sales).

Customer feedback: Despite such critical comments, the 2003 customer satisfaction survey (i.e., two years after the survey that prompted the UCO initiative) indicated initial success: Customers perceived an improvement in customer orientation on almost all items, compared with that provided by HighRingTech's competitors. This achievement also appeared in some qualitative statements from customers: 
The local customer service changed very much. Number and quality of visits are outstanding.... The contact persons care more about us than the competition. The service is very good (informant $\mathrm{A}$, development division).

Concerning technical know-how and quality of the products I would say that HighRingTech is the benchmark for the competition (informant B, purchasing division).

This very positive feedback in turn had a positive impact on employees' motivation to work harder to deliver the value promised to the customer.

Other stakeholder feedback: The organization of bi-annual customer events, such as Tech Days and industry forums, was a viable way to meet customers, supply chain partners, consultants and media. Such events allowed the company to gather feedback regarding the perceived strengths/weaknesses of the UCO program, to integrate company external UCO perspectives into the program, to better understand their needs, and to enhance networking.

Reflection on customer satisfaction and competitor standing: As of 2010, the customer remained at the center of HighRingTech's brand promise. Satisfaction surveys in 2005, 2007, and 2009 showed steady improvement, though the ratings varied somewhat. Some business areas reached their target score of 8.0 for overall customer satisfaction, but others lagged behind. In automotive sales, overall ratings improved from 7.4 in 2001 to 7.6 in 2003; the results for 2005-2009 showed slight further improvement. Even though this group enhanced its performance on most criteria (cf. the price-performance ratio), it still earned lower ratings than its competitors.

\section{Brand strategy formation, group, and brand manifestations}

In this section, we illustrate how brand strategy formation integrates the people who participate in the process, the manifestations that make the brand strategy subject to experience, and the situational context associated with this single, ongoing, recursive, interactive process. Brand actors, both internal and external to the organization, interact socially and produce brand strategy manifestations. Brand strategy knowledge and 
manifestations are continuously co-created and co-constructed; they also are simultaneously implemented, which then influences the ongoing interaction (see Figure 3).

\{Insert Figure 3 around here $\}$

\subsection{Brand strategy formation}

Brand strategy formation constitutes an emerging, complex system of brand knowledge that emerges continuously from a strategy-relevant social interaction process. This complex system is consensual but not uniform. It consists of both shared (Whittington, 2006) and more peripheral elements.

The core contains the consensual elements shared by all members of the strategy group, independent of their specific context (e.g., geographic region, functional area, hierarchical level, team membership, decision problem); for HighRingTech, the central goal of becoming more customer oriented was generally understood and shared by most employees and company partners. This intersubjectivity enables group members to work in a coordinated fashion (Eden \& Ackermann, 1998; Mezias et al., 2001; Van der Heijden \& Eden, 1998).

Situational-specific knowledge and practices also are distributed across members. These peripheral elements allow individual actors to adapt their actions flexibly to operational needs, without jeopardizing the core content of the strategy. For HighRingTech, the practices used to become more customer oriented differed across departments and encompassed various languages, for example. The context-specific brand knowledge of individual members in the strategy interest group may overlap, but it also can be contradictory, as demonstrated in the critical comments about and challenges associated with brand strategy formation. Yet even when employees expressed very different representations of their reality, they widely agreed on the way to frame those depictions (Fiol, 1994). Garud and Rappa (1994) call attention to the enactment of a belief system over time, which they describe as a process that places paradoxical demands on individuals: They must believe in their own realities to make 
progress in their chosen paths and convince others, but at the same time, they must be ready to disbelieve their realities and embrace an emerging shared reality, even if it does not match theirs. Therefore, alternative versions of the same brand strategy existed across individuals and for each individual. Depending on the specific context, the different versions then get activated in memory (Barsalou, 1999).

The performance measure (i.e., the satisfaction survey) in our case study also reveals that despite their socialization, actors participating in ongoing communicative processes adapted their brand knowledge and behavior incrementally. Over time, social interaction appears to lead to consensus about the meaning of relevant stimuli and appropriate actions. The interpretation of branding stimuli thereby becomes socially constructed (Alvesson \& Karreman, 2000) and grants organizational members a form of orientation. The resulting complex system of branding knowledge and feelings, based partly on intentional efforts and partly on unintentional ones, continually gets shaped by and shapes the ongoing social interaction process. This conceptualization reflects Mezias et al.'s (2001) claim that strategy development and implementation are intertwined, such that decisions commit organizations to proceed in a certain way, and organizational commitment follows action as much as action follows commitment (Mintzberg \& Waters, 1985). In line with De Wit and Meyer (2003), we propose that brand strategies are formed and implemented simultaneously, in intentional and unintentional ways.

\subsection{Brand strategy formation group}

Our case reveals that designated, self-interested, and self-selected actors all engage in ongoing interactions focused on strategically relevant brand stimuli. Social interaction is a public process, in the sense that it is open to all who are interested and feel free and empowered to participate. Depending on the organizational structure, the predominant values and norms that guide acceptable behavior, the management systems, and the resources and power available to 
members of the organization and external stakeholders (Corner, Kinicki, \& Keats, 1996; Walsh \& Fahey, 1986), social interactions will be more or less intense. Some actors (in this study, core members of the top management team, external creative agency, consultants) enter into direct verbal or nonverbal contact; others communicate only in indirect or virtual manners (e.g., supporters of core members, such as employees further down the hierarchy and market researchers). Contacts are formal or informal (Balogun \& Johnson, 2005; Mumby \& Clair, 1997).

Furthermore, the brand strategy interest group is not homogeneous: Participants play different roles, with some more intensely involved than others. In our case study, the top management team represented the core members of the brand strategy interest group. However, neglecting the role of "peripheral" members (i.e., employees who are not directly involved in branding strategies but still provide important inputs) located throughout the company would mean disregarding potentially important cocreators of and contributors to the ongoing social interaction. For example, selected task forces and UCO champions, across the hierarchy, engaged in brand strategy development and played key roles in the social interaction process. These employees improved entire processes to become more customer oriented, gave feedback to top management of what worked and what did not; UCO champions facilitated training and information flow and they served as role models. This team was rather cohesive, so members actively participated in the ongoing process.

The team is a socially relevant stimulus as well. Through value selling-based training, members effectively introduced and represented stimuli to fuel and lead the cultural change in specific directions and in reaction to employees' actions. They also participated in conversations that influenced how an issue would be understood and enacted (Maitlis, 2005; Weick, 2002). For instance, in the production center, the complaint messages of customers 
were put on the wall. While these messages largely were ignored in the beginning, after a while they were picked up by employees as an input to how and where to improve.

\subsection{Brand strategy manifestations}

As part of the brand strategy interaction process, the members of the brand strategy interest group socially constructed and created manifestations of the branding strategy. These manifestations are both objects of use and simplified representations of the meaning of the strategy, presented as signs. Through the use of those signs, members of a strategy interest group ascribe ontological reality to their organization (Durkheim, 1994), even if they never come in actual contact, as is common for many global companies. Manifestations enable the members of an organization to experience the abstract meaning of a brand strategy (e.g., Customer Orientation First) by transforming it into more familiar forms of organizational reality, such as objects, people, organizational structures, rules of behavior, practices, management systems, or resource allocations (Weick, 1985). The manifestations then represent the organizational context that surrounds strategically relevant social interactions. Some manifestations are typical to the brand strategy and represent stable elements of the organization's internal environment. Others vary depending on the specific situation. In our case study, the strategic brand objective was to become more customer focused, and management, staff, and external stakeholders worldwide could experience this rather abstract concept through a consistent visual design (e.g., signage), the careful development of new products and services, or the substantial resources available for employee training and education. More peripheral, situation and cultural context-specific manifestations included sponsored events and managerial communication.

\section{Conclusions}

We started with an assertion about the continuing need for empirical research that details the dynamics of brand strategy formation. By drawing on strategy-as-practice research, we 
consider the influence of brand actors, beyond the top management team, and offer empirical insights into social interactive processes; our findings thus contribute to calls for further research in this area (Mühlbacher \& Hemetsberger, 2008; Roper \& Davies, 2007). In contrast with a traditional brand strategy perspective, which tends to find intentional branding decisions even where none exist, we investigate the influence of the situational context on brand strategy formation.

\subsection{Managerial implications}

The findings give rise to several managerial implications. First, our analysis of the roles that the members of a B2B organization perceive for themselves during strategy formation offers a better understanding of the interplay among these various actors, who together continuously form the strategy. We thus identify the key role of internal communication campaigns for the success of brand strategy formation, along with several practices of such campaigns. Practitioners thus should recognize that organizational limits are permeable to varying extents, depending on the stakeholder context (e.g., capital owners, employees, suppliers, consultancies, customers).

Second, it is critical to observe ongoing brand strategy-relevant interactions in organizations, in addition to individual sense-making and sense-giving processes. Doing so gives practitioners a better understanding of how branding strategy in a B2B context forms as a complex system of knowledge and practices and how it simultaneously influences brand strategy through an ongoing discourse.

Third, the findings underpin the influence that the situational context (i.e., individual, business group-specific/organizational, or market-related) has on brand strategy formation.

Fourth, our discussion of strategy formation, brand strategy formation groups, and brand strategy manifestations demonstrates how the formation integrates people who participate in the process, the manifestations that make the brand strategy subject to experience, and the 
situational context into a single, ongoing, recursive, interactive process. Thus brand strategy knowledge and manifestations of brand strategy get continuously co-created and coconstructed; they also are simultaneously implemented.

\subsection{Limitations and further research}

As is the case for most research, our study contains several limitations that affect our interpretations and demand consideration; these limitations also suggest directions for further research. First, studies of brand strategy formation might be improved by real-time, longitudinal analyses, rather than using historical information and interviewee recall. Additional studies should examine brand strategy formation as part of a longitudinal, participant-observer investigation.

Second, our study focuses on a European-based organization, which provides a benchmark for analyzing brand strategy formation in different countries. Examinations of cross-cultural differences in brand strategy formation could help international managers determine whether they should adapt their brand strategy formation to different cultures or if a global effort is feasible.

Third, the study context — adding another brand value rather than starting a corporate brand from scratch-may limit the transferability of our findings. Further research is needed to uncover the full range of possible brand strategy formations required to develop B2B brands.

\section{References}

Aaker, D. A., \& Joachimsthaler, E. (2000). Brand leadership. New York: Free Press.

Alvesson, M., \& Karreman, D. (2000). Taking the linguistic turn in organizational research. Journal of Applied Behavioral Science, 36 (2), 136-158.

Aurand, T., Gorchels, L., \& Bishop, T.R. (2005). Human resource management's role in internal branding: an opportunity for cross-functional brand message synergy. Journal of Product \& Brand Management, 14 (3), 163-169. 
Balmer, J.M.T., \& Gray, E.R. (2003). Corporate brands: what are they? What of them? European Journal of Marketing, 37 (7/8), 972-997.

Balmer, J.M.T., \& Wilson, A. (1998). Corporate identity: there is more to it than meets the eye. International Studies of Management \& Organization, 28 (3), 12-31.

Balogun, J., \& Johnson, G. (2004). Organizational restructuring and middle manager sensemaking. Academy of Management Journal, 47 (4), 523-549.

Balogun, J., \& Johnson, G. (2005). From intended strategies to unintended outcomes: the impact of change recipient sensemaking. Organization Studies, 26 (11), 1573-1601.

Barsalou, L.W. (1999). Perceptional symbol systems. Behavioral and Brain Science, 22, 577660.

Bendixen, M., Bukasa, K.A., \& Abratt, R. (2004). Brand equity in the business-to-business market. Industrial Market Management, 33 (5), 371-380.

Beverland, M.B., Kates, S.M., Lindgreen, A., \& Chung, E. (2010). Exploring consumer conflict management in service encounters. Journal of the Academy of Marketing Science, $38(5), 617-633$.

Beverland, M.B., \& Lindgreen, A. (2002). Using country-of-origin in strategy: the importance of context and strategic action, Journal of Brand Management, 10 (2), 147-167.

Beverland, M.B., \& Lindgreen, A. (2010). What makes a good case study? A positivist review of qualitative case research published in Industrial Marketing Management, 19712006. Industrial Marketing Management, 39 (1), 56-63.

Beverland, M.B, Napoli, J., \& Lindgreen, A. (2007). Industrial global brand leadership: a capabilities view. Industrial Marketing Management, 36 (8), 1082-1093.

Burmann, C., \& Zeplin, S. (2005). Building brand commitment: a behavioural approach to internal brand management. Journal of Brand Management, 12 (4), 279-300. 
Chia, R. (2003). Strategy-as-practice: reflections on the research agenda, European Management Review, 1 (1), 29-34.

Corner, P.D., Kinicki, A.J., \& Keats, B. (1994). Integrating organisational and individual information processing perspectives on choice. Organisation Science, 5 (3), 294-308.

Davis, S., \& Dunn, M. (2002). Building the brand-driven business: operationalize your brand to drive profitable growth. Hoboken, NJ: John Wiley \& Sons.

Dawson, P. (2003). Understanding organisational change: contemporary experience of people at work. London: Sage Publications.

de Chernatony, L. (2010). From brand vision to brand evaluation. Oxford: ButterworthHeinemann.

de Chernatony, L., Drury, S., \& Segal-Horn, S. (2006). Communicating services brands' values internally and externally. The Service Industries Journal, 26 (8), 819-836.

De Wit, B., \& Meyer, R. (2003). Strategy-process, content, context, 3d. ed. London: International Thomson Business Press.

Durkheim, E. (1994). Die elementaren Formen des religiösen Lebens, No.1125. Frankfurt a.M.: Suhrkamp - TB Wissenschaft.

Eden, C., \& Ackermann, F. (1998). Making strategy: the journey of strategic management. London: Sage Publications.

Eisenhardt, K.M. (1989). Building theories from case study research. Academy of Management Review, 14 (4), 532-550.

Fiol, M.C. (1994). Consensus, diversity, and learning in organizations. Organization Science. 5 (3), 403-420.

Floyd, S.W., \& Wooldridge, B. (1997). Middle management's strategic influence and organizational performance. Journal of Management Studies, 34 (3), 465-485.

Garud, R., \& Rappa, M. (1994). A social-cognitive model of technology evolution: the case of 
cochlear implants. Organization Science, 5 (3), 344-362.

Glynn, M.S. (2010). The moderating effect of brand strength in manufacturer-reseller relationships. Industrial Marketing Management, 39 (8), 1226-1233.

Hatch, M.J., \& Schultz, M. (2001). Are the strategic stars aligned for your corporate brand? Harvard Business Review, 4 (1), 129-134.

Hatch, M.J., \& Schultz, M. (2003). Bringing the corporation into corporate branding. European Journal of Marketing, 37 (7/8), 1041-1064.

Hendry, J. (2000). Strategic decision making, discourse, and strategy as social practice. Journal of Management Studies, 37 (7), 955-979.

Homburg, C., Workman, J., \& Jensen, O. (2000). Fundamental changes in marketing organization: the movement toward a customer-focused organizational structure. Journal of the Academy of Marketing Science, 28 (4), 459-478.

Ind, N. (2007). Living the brand: how to transform every member of your organization into a brand champion. London: Kogan Page.

Jarzabkowski, P. (2004). Strategy as practice: recursive, adaptive and practices-in-use. Organization Studies, 25 (4), 529-560.

Jarzabkowski, P. (2005). Strategy as practice: an activity-based approach. London: Sage Publications.

Jarzabkowski, P., \& Seidl, D. (2005). The role of meetings in the social practice of strategy. Organization Studies, 29 (11), 1391-1426.

Jarzabkowski, P., Balogun, J., \& Seidl, D. (2007). Strategizing: the challenges of a practice perspective. Human Relations, 60 (1), 5-27.

Jawahar, I., \& McLaughlin, G. (2001). Toward a descriptive stakeholder theory: an organizational life cycle approach. Academy of Management Review, 26 (3), 397-414.

Johnson, G., Langley, A., Melin, L., \& Whittington, R. (2007). Strategy as practice: research 
directions and resources. Cambridge: Cambridge University Press.

Johnson, G., Melin, L., \& Whittington, R. (2003). Micro strategy and strategizing: towards an activity-based view? Journal of Management Studies, 40 (1), 3-22.

Keller, K.L. (2003). Strategic brand management: building, measuring and managing brand equity, 2nd ed. Upper Saddle River, NJ: Prentice Hall.

Kuhn, K., Alpert, F., \& Pope, N.K. (2008). Developing and testing an application of Keller's brand equity model in a B2B context. Qualitative Market Research: An International Journal, 11 (1), 40-58.

Lambkin, M.C., \& Muzellec, L. (2010). Leveraging brand equity in business-to-business mergers and acquisitions. Industrial Marketing Management, 39 (8), 1234-1239.

Larkin, T.J., \& Larkin, S. (1996). Reaching and changing frontline employees. Harvard Business Review, 74 (3), 95-104.

Laroche, H. (1995). From decision to action in organizations: decision-making as a social representation. Organization Science, 6 (1), 62-75.

Lencioni, P.M. (2002). Make your values mean something. Harvard Business Review, 80 (4), $5-9$.

LePla, J.F., \& Parker, L.M. (1999). Integrated branding: becoming brand-driven through companywide action. London: Free Press.

Lincoln, Y.S., \& Guba, E. (1985). Naturalistic inquiry. Beverly Hills, CA: Sage Publications. Lindgreen, A., \& Beverland, M.B. (2009). Hush, it's a secret: how Trappist breweries create and maintain images of authenticity by engaging in experiential marketing. In Lindgreen, A., Vanhamme, J., \& Beverland, M.B. (Eds.). Memorable Customer Experiences, pp. 4368. Aldershot: Gower Publishing. 
Lindgreen, A., Beverland, M.B., \& Farrelly, F. (2010). From strategy to tactics: building, implementing, and managing brand equity in business markets. Industrial Marketing Management, 39 (8), 1223-1225.

Lindgreen, A., Maon, F., Xu, T., \& Wilcock, J. (2011). Corporate social responsibility brand leadership: a multiple case study. European Journal of Marketing, in press.

Low, J., \& Blois, K. (2002). The evolution of generic brands in industrial markets: the challenges to owners of brand equity. Industrial Market Management, 31 (5), 385-392.

Macrae, C. (1999). Brand reality editorial. Journal of Marketing Management, 15 (1/3), 1-24.

Maitlis, S. (2005). The social processes of organizational sensemaking. Academy of Management Journal, 48 (1), 21-49.

Maitlis, S., \& Lawrence, T.B. (2007). Triggers and enablers of sensegiving in organizations. Academy of Management Journal, 50 (1), 57-84.

Mezias, J.M., Grinyer, P., \& Guth, W.D. (2001). Changing collective cognition: a process model for strategic change. Long Range Planning, 34 (1), 71-93.

Mintzberg, H. (1994). The rise and fall of strategic planning. New York: Free Press.

Mintzberg, H., \& Raisinghani, D. (1976). The structure of 'unstructured' decision processes. Administrative Science Quarterly, 21 (2), 246-276.

Mintzberg, H., \& Waters, J. (1985). Of strategies, deliberate and emergent. Strategic Management Journal, 6 (3), 257-272.

Mitchell, P., King, J., \& Reast, J. (2001). Brand values related to industrial products. Industrial Marketing Management, 30 (5), 415-425.

Mudambi, S. (2002). Branding importance in business-to-business markets: Three buyer clusters. Industrial Marketing Management, 31 (6), 525-533. 
Mühlbacher, H., \& Hemetsberger, A. (2008). What the heck is a brand? An attempt of integration and its consequences for research and management. Proceedings of the $7^{\text {th }}$ International Congress Marketing Trends, Venice.

Mumby, D.K., \& Clair, R.P. (1997). Organizational discourse. In van Dijk, T.A. (Ed.), Discourse as social interaction, Discourse studies: a multidisciplinary introduction, Vol. 2, pp. 181-205. London: Sage Publications.

Persson, N. (2010). An exploratory investigation of the elements of B2B brand image and its relationship to price premium. Industrial Marketing Management, 39 (8), 1269-1277.

Roper, S., \& Davies, G. (2007). The corporate brand: dealing with multiple stakeholders. Journal of Marketing Management, 23 (1), 75-90.

Rouleau, L. (2005). Micro-practices of strategic sensemaking and sensegiving: how middle managers interpret and sell change every day. Journal of Management Studies, 42 (7), $1413-1441$.

Salzer-Mörling, M., \& Strannegard, L. (2004). Silence of the brands. European Journal of Marketing, 38 (1/2), 224-238.

Schilit, W.K. (1987). Upward influence activity in strategic decision making. Group \& Organization Management, 12 (3), 343-368.

Schultz, M., Hatch, M.J., Larsen, M.H., \& Van Riel, C.B. (2002). Corporate communication orchestrated by a sustainable corporate story. In Schultz, M., Hatch, M.J., \& Larsen, M.H. (Eds.). Expressive organization, pp. 157-181. Oxford: Oxford University Press.

Smith, K.G., Smith, K. A., Sims, H.P. Jr., O’Bannon, D.P., \& Scully, J.A. (1994). Top management team demography and process: the role of social integration and communication. Administrative Science Quarterly, 39 (3), 412-439.

Spiggle, S. (1994). Analysis and interpretation of qualitative data in consumer research. Journal of Consumer Research, 21 (3), 491-503. 
Strauss, A., \& Corbin, J. (1998). Basics of qualitative research, 2nd ed. Newbury Park, CA: Sage Publications.

Thomas, J.B., Clark, S.M., \& Gioia, D. A. (1993). Strategic sensemaking and organizational performance: linkages among scanning, interpretation, action and outcomes. Academy of Management Journal, 36 (2), 239-270.

Thomas, J.B., Shankster, L.J., \& Mathieu, J.E. (1994). Antecedents to organizational issue interpretation: the roles of single-level, cross level, and content cues. Academy of Management Journal, 37 (5), 1252-1284.

Thomson, K., de Chernatony, L., Arganbright, L., \& Khan, S. (1999). The buy-in benchmark: how staff understanding and commitment impact brand and business performance. Journal of Marketing Management, 15 (8), 819-835.

van de Ven, B. (2008). An ethical framework for the marketing of corporate social responsibility. Journal of Business Ethics, 82, (2), 339-352.

Van der Heijden, K., \& Eden, C. (1998). The theory and praxis of reflective learning in strategy making. In: Eden, C., \& Sender, J. C. (Eds.). Managerial and organizational cognition, pp. 58-75. London: Sage Publications.

Vallaster, C., \& de Chernatony, L. (2006). Internal brand building and structuration: the role of leadership. European Journal of Marketing, 7 (8), 761-784.

Walsh, J.P., \& Fahey, L. (1986). The role of negotiated belief structures in strategy making. Journal of Management, 12 (3), 325-338.

Webster, F., \& Keller, K.L. (2004). A roadmap for branding in industrial markets. Brand Management, 11 (5), 388-402.

Weick, K.E. (1985). The significance of corporate culture. In Frost, P.J., Moore, L.F., Louis, M.R., Lundberg, C.C., \& Martin, J. (Eds.). Organizational culture, pp. 381-389. Beverly Hills, CA: Sage Publications. 
Weick, K.E. (2002). Making sense of the organisation. Oxford: Blackwell Publishers.

Whittington, R. (2003). The work of strategizing and organizing: for a practice perspective. Strategic Organization, 1 (1), 119-127.

Whittington, R. (2006). Completing the practice turn in strategy research. Organization Studies, 27 (5), 613-634.

Wooldridge, B., \& Floyd, S.W. (1990). The strategy process, middle management involvement, and organizational performance. Strategic Management Journal, 11 (3), 231241.

Woodside, A. (2010). Case study research: theory, methods and practice. Bingley: Emerald Group Publishing.

Workman, J.P. Jr., Homburg, C., \& Jensen, O. (2003). Intraorganizational determinants of key account management effectiveness. Journal of the Academy of Marketing Science, 31 (1), 3-21.

Yin, R.K. (2003). Case study research: design and methods, 3rd ed. Thousand Oaks, CA: Sage Publications. 
Table 1: Interview sample

\section{Unit of Analysis}

\section{Function}

\section{HighRingTech: Vibration Control Europe}

1
2
3
4
5

HighRingTech: Vibration Control America

1

2

3

Vibratech Europe

1

2

3

4

5

6

7

External Consultant

Supplier
Chair of the board (active)

Internal communications manager (active)

Director of sales (active)

Logistics manager (passive)

Key account manager (active)

Internal communications manager (passive)

Director of sales (active)

Product developer in chief (passive)

Team coordinator, Ultimate Customer Orientation (UCO) (passive)

Sales manager VK 1 (passive)

Sales manager VK 2 (passive)

Worker 1 at production line VK 1 (passive)

Worker 2 at production line VK 1 (passive)

Customer complaint manager (passive)

Worker 1 at production line VK 2 (passive)

Head of project (active)

Change agent (active)

Key account manager (passive)

Director \& key account manager (passive)

External creative agency 
Table 2: Interview protocol, topics, and codes for analysis

\begin{tabular}{ll}
\hline Target Topics / Codes for Analysis \\
\hline
\end{tabular}

\section{HighRingTech Employees}

What was the motivation to start with UCO?

Reasons to launch UCO and related aims

What were major challenges throughout this program? What were major obstacles from different areas / people?

Situational contexts, problems associated with the

Who were major participants and what was their role? program

Brand actors and roles, social interaction, communication

What were single steps, brand activities, etc?

Brand strategy formation practices

What were moments of success?

Levels of success

External Consultant, Supplier, Market Research Company, Creative Agency

What were major challenges throughout this program?

What were major obstacles from different areas / people?

Situational contexts, problems associated with the

What was your role? program

Brand actors and roles, social interactions, communication

What were single steps, brand activities, etc.?

Brand strategy formation practices

What were moments of success?

Levels of success 


\section{Table 3: Criteria for assessing research quality: trustworthiness}

Confirmability $\rightarrow$ Interviews with knowledgeable informants from internal and external to case company. Discussions with academic colleagues; presentation of research findings at brand marketing conference. Two researchers analyzed the collected data, as well as tacked between literature and data. These efforts expand and refine our interpretation of the findings.

Credibility $\rightarrow$ Two researchers set up the research and interpreted the findings. All informants were invited to provide feedback after the analysis.

Dependability $\rightarrow$ The historical development of branding was discussed.

Fit $\rightarrow$ The question of whether our findings were in line with what we examined was addressed through credibility, dependability, and confirmability (Beverland, Kates, Lindgreen, \& Chung, 2010).
Generality $\rightarrow$ The number and length of interviews uncovered multiple aspects of corporate brand strategy formation.

Integrity $\rightarrow$ Interview questions were nonthreatening and allowed informants to present the material in their own terms. Thus informants were open about the research issues.

Transferability $\rightarrow$ We provided background information on the case company and located the company within its industry sector. We gave detailed descriptions of the company's background and brand strategy development. We employed a standardized interview protocol, clear procedures for data analysis, and a database that offers input for our qualitative analysis.

Understanding $\rightarrow$ Informants were invited to provide feedback on initial interpretations. We presented the initial findings at a brand marketing conference, inviting colleagues to question our findings. 
Figure 1: Organizational structure of HighRingTech

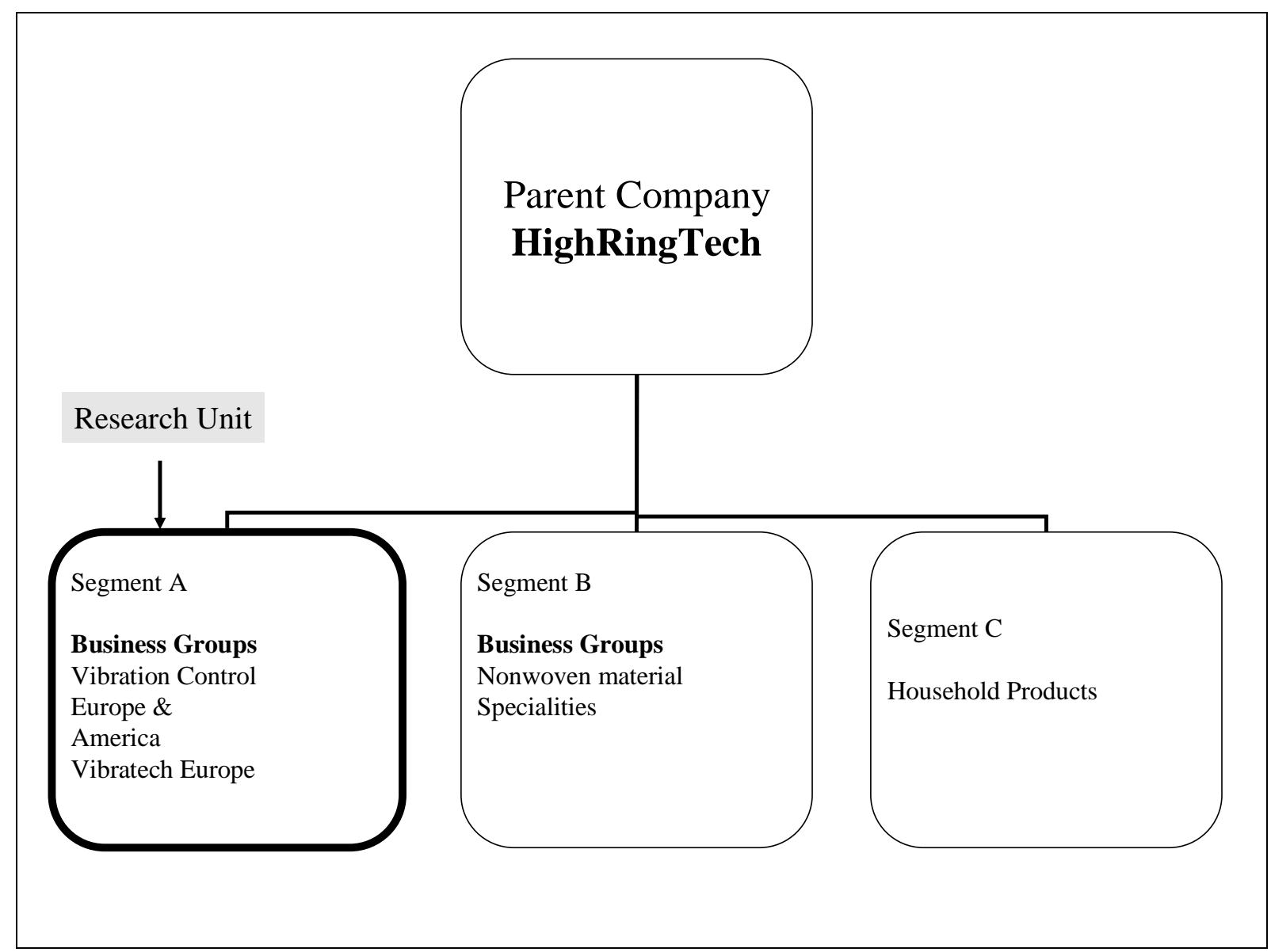


Figure 2: Brand champions involved in the UCO transfer process

Organisational Hierarchy

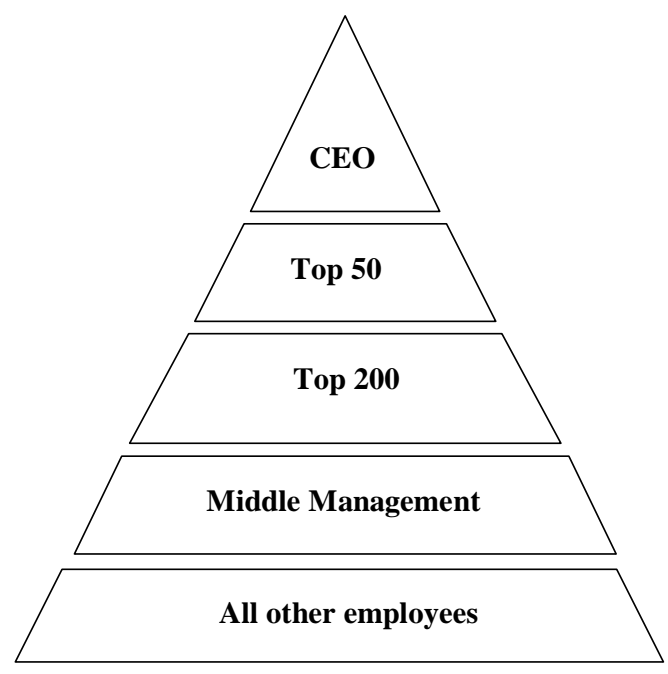

Brand Champions

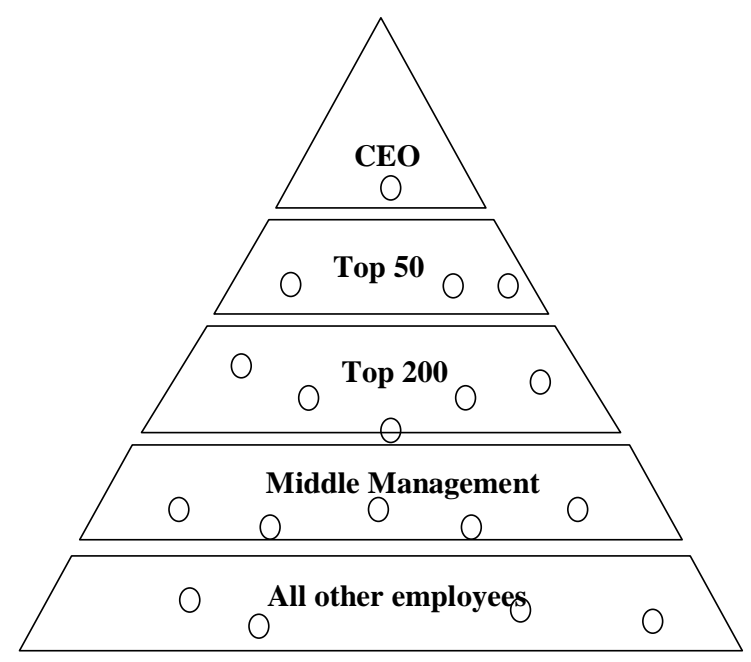

○ 20 selected Brand Champions 
Figure 3: Brand strategy formation and underlying dynamics

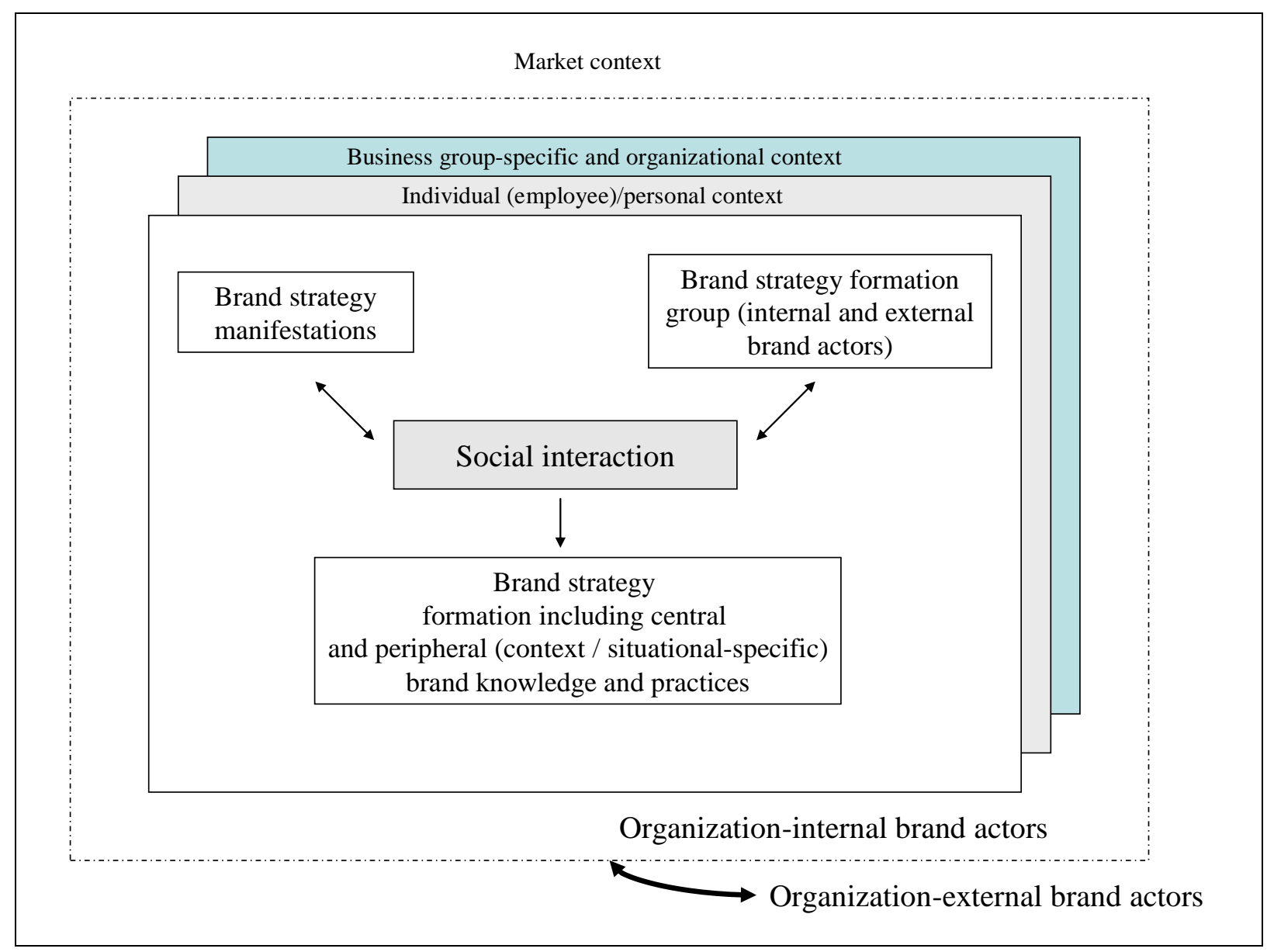




\section{Biographical notes}

Dr. Christine Vallaster is an associate professor at the Institute for Entrepreneurship at the University of Liechtenstein. Her research activities evolve around the topic of strategic brand management. She publishes regularly in both academic and practitioner journals, including California Management Review, the European Journal of Marketing, and Industrial Marketing Management. Next to teaching and research activities, Dr. Vallaster works as a consultant for strategic brand projects in nationally and internationally operating companies.

Dr. Lindgreen is professor of marketing at the University of Cardiff's Business School and visiting professor at IESEG School of Management. His recent publications have appeared in Business Horizons, California Management Review, the European Journal of Marketing, Industrial Marketing Management, the Journal of Advertising, the Journal of Business Ethics, the Journal of the Academy of Marketing Science, the Journal of Marketing Management, the Journal of Product Innovation Management, Psychology \& Marketing, and Supply Chain Management, among others; he is the recipient of the "Outstanding Article 2005" award from Industrial Marketing Management. His most recent books are Managing Market Relationships, Market Orientation, Memorable Customer Experiences, The Crisis of Food Brands, and The New Cultures of Foods. He has two books forthcoming: (with Philip Kotler,

François Maon, Joëlle Vanhamme) A Stakeholder Approach to Corporate Social Responsibility (with François Maon, Sankar Sen, and Joëlle Vanhamme) Sustainable Value Chain Management. 